\title{
Bulk density of soil depending on the farming systems and soil tillage for growing spring wheat in the Right Bank Forest- Steppe of Ukraine
}

\author{
Oleksandr Dudka, Semen Tanchyk, Oleksandr Pavlov \\ National University of Life and Environmental Sciences of Ukraine, Ukraine \\ Corresponding Author: Oleksandr Dudka, dudka198@ukr.net
}

\begin{abstract}
The article presents the results of research on the impact of three farming systems with different resource content - industrial, environmental, and organic, and four systems of basic tillage - plowing $20-22 \mathrm{~cm}$, chisel plowing $20-22 \mathrm{~cm}$, disking $10-12 \mathrm{~cm}$ and disking $6-8$ $\mathrm{cm}$ on bulk density of typical chernozem and yield of spring wheat in the right-bank ForestSteppe of Ukraine.

Given the results of research by scientists around the world, it is important to improve the agrophysical properties of soils, including their bulk density.

According to the results of a three-year field experiment conducted in the field crop rotation of the experimental field of NULES of Ukraine, the increase in soil bulk density occurred gradually from the upper to lower layers and from the pre-sowing period to harvesting in all variants of farming and tillage systems.

There was a significant decrease in the bulk density of the soil before sowing to $1.06 \mathrm{~g} / \mathrm{cm}^{3}$ in $0-10 \mathrm{~cm}$ layer in environmental farming and up to 1.05 - organic. While in the control, this figure was $1.12 \mathrm{~g} / \mathrm{cm}^{3}$. A similar trend was observed in the layers of $10-20$ and $20-30 \mathrm{~cm}$. On average, this decrease was $4.5 \%$ for the environmental farming and $5.1 \%$ for the organic farming. The advantage of these systems remained until the harvest of spring wheat.

According to ANOVA the conservation tillage variants provided significantly lower parameters of the bulk density before sowing the crop in the upper $-0-10 \mathrm{~cm}$ layer of soil, compared to plowing. In the deeper layers of the soil $-10-20$ and $20-30 \mathrm{~cm}$, no significant differences between plowing and chisel plowing were found. Variants with disking led to a significant increase in the soil bulk density to $1.21 \mathrm{~g} / \mathrm{cm}^{3}$ at a depth of $10-20 \mathrm{~cm}$ and $1.24-1.25$ $\mathrm{g} / \mathrm{cm}^{3}-20-30 \mathrm{~cm}$ preserved until the harvest of the culture.

The application of organic fertilizers in combination with the cultivation of green manure crops in crop rotation allows to limit the impact of minimizing the primary tillage on its bulk density. Regardless of the variant of soil tillage in environmental and organic farming, the bulk soil density on average over the years of research did not exceed $1.3 \mathrm{~g} / \mathrm{cm}^{3}$, which indicates the important role of organic matter in improving the agrophysical parameters of chernozems.
\end{abstract}

Keywords: spring wheat, bulk density, industrial, environmental, and organic farming systems, plowing, chiseling, disking, yield.

\section{Introduction}

The problem of soil degradation in Ukraine, especially chernozems, is very acute. Many researchers see ways to solve it through the integrated use of tillage, crop residue management, use of 
cover crops, fertilizers and other activities carried out in a scientifically sound farming system $[1,2,3$, 4].

Excessive bulk density of soil, which for cereals on typical chernozems is above $1.4 \mathrm{~g} / \mathrm{cm}^{3}$, can cause a few negative phenomena, including deterioration of water, air and other soil regimes, increased traction of tillage units in arable soils, which increases energy consumption [5, 6]. According to research by many scientists, improving the agrophysical properties of the soil, including its bulk density, is possible using organic fertilizers, cover crops and minimize tillage in farming systems. Review data from Blanco-Canqui $\mathrm{H}$. and Ruis S. J. indicate that many researchers around the world have managed to reduce soil compaction from 0 to $29 \%$ (average $5 \%$ ) by growing cover crops. The magnitude of the improvement significantly depended on the location of the research and the features of green mass management of cover crops [7].

An analysis of recent research by scientists on the impact of tillage on its bulk density shows a significant increase in this indicator while minimizing tillage compared to traditional plowing. However, as a rule, this increase was not critical for the crop, and the yield was at the level of control, or even exceeded it, especially in the options with the application of organic fertilizers $[8,9,10,11$, $12]$.

\section{Materials and methods}

The purpose of the research is to establish the patterns of changes in the bulk density of typical chernozem depending on the farming systems and tillage in spring wheat crops of the Right Bank Forest-Steppe of Ukraine.

The research was conducted during 2018-2020 in the conditions of a stationary 2-factor experiment of the Department of Agriculture and Herbology at the Agronomic Research Station of NULES of Ukraine.

We studied three variants of the farming system (factor A) and four variants of the primary tillage system (factor B). Spring wheat was grown in the following crop rotation: soybean - winter wheat sunflower - spring wheat - corn.

The content of gradations of the first factor (A) of farming systems is based on the level of use of resources in them to expand the reproduction of soil fertility. The control variant was an industrial farming system. It included the use of 12 tons of organic (manure) and $300 \mathrm{~kg}$ of active substance of mineral fertilizers $\left(\mathrm{N}_{92} \mathrm{P}_{100} \mathrm{~K}_{108}\right)$ per hectare in crop rotation. $290 \mathrm{~kg} / \mathrm{ha}$ of active ingredient $\left(\mathrm{N}_{90} \mathrm{P}_{90} \mathrm{~K}_{100}\right)$ was applied directly to the spring wheat. The recommended pesticides were applied in full in this system. Manure was applied to sunflower and corn for grain with rates of $30 \mathrm{t} / \mathrm{ha}$, which averaged $12 \mathrm{t} / \mathrm{ha}$ for the entire crop rotation. The index of the ratio of applied mineral fertilizers to organic is $25(300 / 12)$. This indicates the industrial nature of this farming system.

Models of environmental and organic farming were compared with the control variant.

In environmental farming, $24 \mathrm{t} / \mathrm{ha}$ of organic and $150 \mathrm{~kg} / \mathrm{ha}$ of NPK mineral fertilizers in the active substance $\left(\mathrm{N}_{47} \mathrm{P}_{78} \mathrm{~K}_{25}\right)$ were applied per hectare of arable land. $130 \mathrm{~kg} / \mathrm{ha}$ of active substance $\left(\mathrm{N}_{50} \mathrm{P}_{20} \mathrm{~K}_{60}\right)$ of mineral fertilizers was applied directly to the spring wheat. Under this system, 12 tons per hectare of crop rotation area of manure and $12 \mathrm{t} / \mathrm{ha}$ of green mass of green manure (white mustard) were applied, which were sown after harvesting winter and spring wheat. Pesticides in this system were applied according to the criterion of ecological and economic threshold of the number of harmful organisms. The index of the ratio of applied mineral fertilizers to organic is $6.2(150 / 24)$.

In organic farming, only 24 t/ha of organic fertilizers were used in crop rotation -12 tons per hectare of crop rotation area of manure and $12 \mathrm{t} / \mathrm{ha}$ of green mass of greens (white mustard), which were sown after harvesting winter and spring wheat. The index of the ratio of applied mineral fertilizers to organic is $0(0 / 24)$.

In the models of farming systems, four variants of the primary tillage (factor B) for spring wheat were studied: 1) plowing - 20-22 cm (control); 2) chisel plowing - 20-22 cm; 3) disking - 10-12 cm; 4) disking $-6-8 \mathrm{~cm}$. The scheme of the experiment is shown in table 1. 
Table 1. Scheme of stationary field experiment

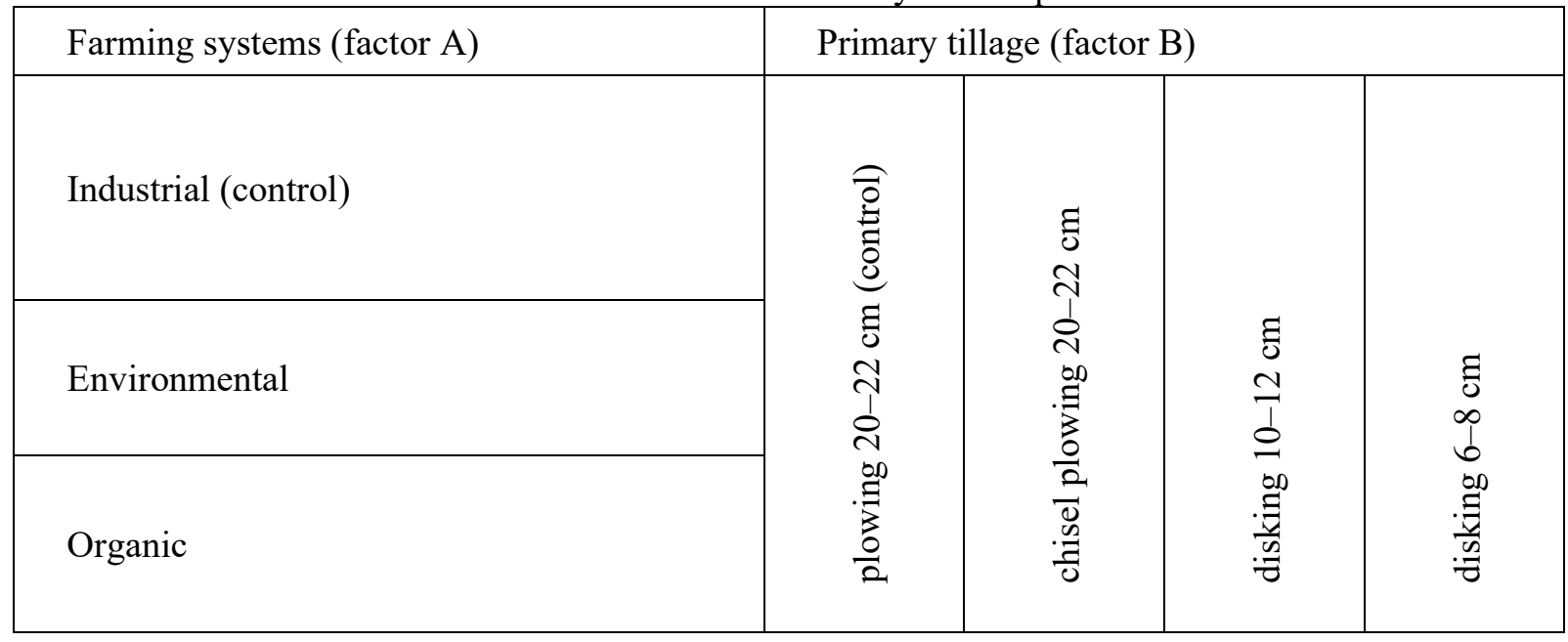

The method of placement of plots is split-plot design. The plots where the primary tillage variants are carried out have a sown area of $280 \mathrm{~m}^{2}(8 \times 35 \mathrm{~m})$ and an accounting area of $225 \mathrm{~m}^{2}(7 \times 32.1 \mathrm{~m})$. The plots where farming systems are used have a sown area of $93.6 \mathrm{~m}^{2}(8 \times 11.7 \mathrm{~m})$ and an accounting area of $75 \mathrm{~m}^{2}(7 \times 10.7 \mathrm{~m})$. Number of replicates in the experiment -4 . Sowing of spring durum wheat Diana was carried out at the temperature of the seed layer $2-3{ }^{\circ} \mathrm{C}$.

The bulk density of the soil was determined by the method of M. A. Kaczynski (cylinder method) according to DSTU ISO 11272-2001. Sampling was performed from layers 0-10, 10-20, 20-30 cm pre-sowing of spring wheat, in the flowering phase and before harvesting [13]. The grain yield was considered in the phase of full ripeness of spring wheat from each variant in all repetitions separately.

Statistical analysis of experimental data was performed using Excel software from MS Office 365 and Statistica 10.

\section{Results and discussion}

The bulk density of the soil is a dynamic quantity and depends on a significant number of indicators, so soil samples were taken during the growing season of spring wheat. There was a gradual increase in bulk density from the pre-sowing period to harvesting. This increase was for all studied variants, regardless of the depth of sampling. Also, the increase in bulk soil density occurred gradually from the upper to the lower layers of the soil in all variants of farming systems and tillage.

If we analyze the average impact of farming systems, it should be noted a significant reduction in bulk density in the variants of environmental and organic farming. This is due to the level of use of resources to reproduce the fertility of the soil in these systems. The use of green manure in crop rotation, in addition to applied $12 \mathrm{t} / \mathrm{ha}$ of manure, allowed to reduce the bulk density of the soil in environmental farming before sowing to $1.06 \mathrm{~g} / \mathrm{cm}^{3}$ in $0-10 \mathrm{~cm}$ layer, in organic farming -1.05 . While in the control, this figure was $1.12 \mathrm{~g} / \mathrm{cm}^{3}$. A similar trend was observed in the layers of $10-20$ and $20-30 \mathrm{~cm}$. On average, this decrease was $4.5 \%$ for the environmental system and $5.1 \%$ for the organic system. The advantage of these systems remained until the harvest of spring wheat (tab. 2).

ANOVA showed that the options of the primary tillage also significantly affected the bulk density. The conservation tillage variants $(\mathrm{CP}, \mathrm{D} 1, \mathrm{D} 2)$ provided significantly lower bulk density parameters in the upper $-0-10 \mathrm{~cm}$ layer of soil compared to plowing. This is due to the location of the most residue of the preceding crops in this layer of soil, which have a positive effect on the development of mesoand microfauna. In the deeper layers of the soil (10-20 and 20-30 cm) no significant differences between plowing and chisel plowing were found. At the time of spring wheat sowing, the bulk density in these tillage variants was $1.18 \mathrm{~g} / \mathrm{cm}^{3}$ in $10-20 \mathrm{~cm}$ thick and $1.22-1.23 \mathrm{~g} / \mathrm{cm}^{3}$ in $20-30 \mathrm{~cm}$, respectively. In both variants with disking (D1, D2) there was a significant increase in soil bulk 
density to $1.21 \mathrm{~g} / \mathrm{cm}^{3}$ at a depth of $10-20 \mathrm{~cm}$ and $1.24-1.25 \mathrm{~g} / \mathrm{cm}^{3}-20-30 \mathrm{~cm}$. In the process of vegetation of spring wheat and before harvesting, the patterns of bulk density, depending on the tillage, were similar.

Table 2. Dynamics of soil bulk density and yield of spring wheat depending on the studied factors, on average for 2018-2020

\begin{tabular}{|c|c|c|c|c|c|c|c|c|c|c|c|}
\hline \multirow{3}{*}{ A } & \multirow{3}{*}{ B } & \multicolumn{9}{|c|}{ Bulk density } & \multirow{3}{*}{ Yield, t/ha } \\
\hline & & \multicolumn{3}{|c|}{ pre-sowing } & \multicolumn{3}{|c|}{ flowering } & \multicolumn{3}{|c|}{ pre-harvesting } & \\
\hline & & $0-10$ & $10-20$ & $20-30$ & $0-10$ & $10-20$ & $20-30$ & $0-10$ & $10-20$ & $20-30$ & \\
\hline \multirow{4}{*}{ I } & $\mathrm{P}$ & 1,16 & 1,22 & 1,24 & 1,22 & 1,29 & 1,31 & 1,23 & 1,26 & 1,30 & 5,1 \\
\hline & $\mathrm{CP}$ & 1,14 & 1,22 & 1,27 & 1,20 & 1,30 & 1,29 & 1,21 & 1,29 & 1,33 & 5,3 \\
\hline & D1 & 1,08 & 1,24 & 1,29 & 1,13 & 1,32 & 1,34 & 1,14 & 1,31 & 1,33 & 4,6 \\
\hline & D2 & 1,08 & 1,25 & 1,28 & 1,13 & 1,32 & 1,34 & 1,14 & 1,31 & 1,32 & 4,1 \\
\hline \multirow{4}{*}{$\mathrm{E}$} & $\mathrm{P}$ & 1,11 & 1,16 & 1,21 & 1,16 & 1,23 & 1,26 & 1,17 & 1,22 & 1,29 & 5,2 \\
\hline & $\mathrm{CP}$ & 1,08 & 1,17 & 1,22 & 1,14 & 1,24 & 1,27 & 1,15 & 1,22 & 1,27 & 5,6 \\
\hline & D1 & 1,03 & 1,20 & 1,23 & 1,08 & 1,26 & 1,30 & 1,09 & 1,24 & 1,29 & 4,8 \\
\hline & D2 & 1,03 & 1,19 & 1,20 & 1,08 & 1,26 & 1,28 & 1,09 & 1,25 & 1,30 & 4,4 \\
\hline \multirow{4}{*}{$\mathrm{O}$} & $\mathrm{P}$ & 1,10 & 1,15 & 1,21 & 1,15 & 1,22 & 1,25 & 1,16 & 1,21 & 1,27 & 2,8 \\
\hline & $\mathrm{CP}$ & 1,07 & 1,15 & 1,20 & 1,13 & 1,22 & 1,24 & 1,14 & 1,21 & 1,26 & 3,1 \\
\hline & D1 & 1,02 & 1,18 & 1,23 & 1,07 & 1,24 & 1,25 & 1,08 & 1,23 & 1,29 & 2,6 \\
\hline & $\mathrm{D} 2$ & 1,02 & 1,18 & 1,23 & 1,07 & 1,25 & 1,26 & 1,08 & 1,23 & 1,30 & 2,2 \\
\hline & $0,(A B)$ & $\mathbf{0 , 0 2 7}$ & 0,016 & 0,018 & $\mathbf{0 , 0 3 0}$ & $\mathbf{0 , 0 1 7}$ & 0,019 & $\mathbf{0 , 0 3 1}$ & $\mathbf{0 , 0 1 7}$ & 0,019 & 0,25 \\
\hline \multicolumn{12}{|c|}{ average for $\mathrm{A}$} \\
\hline & $\mathrm{I}$ & 1,12 & 1,24 & 1,27 & 1,17 & 1,31 & 1,32 & 1,18 & 1,29 & 1,32 & 4,8 \\
\hline & $\mathrm{E}$ & 1,06 & 1,18 & 1,22 & 1,11 & 1,25 & 1,28 & 1,13 & 1,23 & 1,29 & 5,0 \\
\hline & $\mathrm{O}$ & 1,05 & 1,17 & 1,22 & 1,10 & 1,23 & 1,25 & 1,11 & 1,22 & 1,27 & 2,7 \\
\hline & $D_{05}(A)$ & $\mathbf{0 , 0 1 3}$ & 0,008 & 0,009 & 0,015 & 0,009 & 0,010 & $\mathbf{0 , 0 1 5}$ & 0,009 & 0,010 & $\mathbf{0 , 1 3}$ \\
\hline \multicolumn{12}{|c|}{ average for $\mathrm{B}$} \\
\hline & $\mathrm{P}$ & 1,12 & 1,18 & 1,22 & 1,18 & 1,25 & 1,27 & 1,19 & 1,23 & 1,29 & 4,4 \\
\hline & $\mathrm{CP}$ & 1,10 & 1,18 & 1,23 & 1,15 & 1,25 & 1,27 & 1,16 & 1,24 & 1,29 & 4,6 \\
\hline & D1 & 1,04 & 1,21 & 1,25 & 1,09 & 1,27 & 1,30 & 1,10 & 1,26 & 1,30 & 4,0 \\
\hline & D2 & 1,04 & 1,21 & 1,24 & 1,09 & 1,28 & 1,29 & 1,10 & 1,26 & 1,30 & 3,6 \\
\hline & $D_{05}(B)$ & 0,016 & 0,009 & 0,011 & 0,018 & 0,010 & 0,011 & 0,018 & 0,010 & 0,011 & 0,14 \\
\hline
\end{tabular}

$\mathrm{A}$ - farming systems (I - industrial farming, $\mathrm{E}$ - environmental farming, $\mathrm{O}$ - organic farming); $\mathrm{B}$ primary soil tillage $(\mathrm{P}$ - plowing $20-22 \mathrm{~cm}, \mathrm{CP}$ - chisel plowing $20-22 \mathrm{~cm}, \mathrm{D} 1-$ disking $10-12 \mathrm{~cm}$, D 2 - disking $6-8 \mathrm{~cm})$.

The analysis of the interaction of the studied factors indicates that the application of organic fertilizers in combination with the use of green manure crops in crop rotation allows to limit the negative impact of minimizing the main tillage on its bulk density. According to the table 2, regardless of the type of soil tillage, in environmental and organic farming systems, the bulk density of soil on average over the years of research did not exceed $1.3 \mathrm{~g} / \mathrm{cm}^{3}$, which indicates the important role of organic matter in improving agrophysical parameters of chernozems.

The yield of spring wheat significantly depended on the studied farming systems and tillage variants. The environmental system on average exceeded the control by $0.2 \mathrm{t} / \mathrm{ha}$, which is a significant indicator. Organic farming, on the contrary, showed a significant decrease to $2.7 \mathrm{t} / \mathrm{ha}$. Even though the 
bulk density of soil under this system and agrophysical properties in general have improved, crop yields are likely to be affected by other factors, such as weeds, pests, and diseases.

Among the variants for primary tillage, chisel plowing $(4.6 \mathrm{t} / \mathrm{ha})$ provided a significant advantage over plowing (4.0 t/ha). Both disking variants (D1, D2) reduced crop yields to 4.0 and $3.6 \mathrm{t} / \mathrm{ha}$, respectively. We noted an inverse correlation $(\mathrm{r}=-0.85)$ between yield and bulk density of soil in layers of $10-20$ and $20-30 \mathrm{~cm}$.

The optimal combination of variants in the experiment can be considered the use of environmental farming system with chisel plowing of $20-22 \mathrm{~cm}$. This allowed to obtain $5.6 \mathrm{t} / \mathrm{ha}$ of spring wheat grain, which is statistically more than control.

\section{Conclusion}

According to the above results, the environmental and organic farming led to a significant reduction in the bulk density of the soil during the entire growing season of spring wheat by $4.5-5.1 \%$ on average.

The use of disking on 10-12 and 6-8 $\mathrm{cm}$ led to a significant increase in the bulk density of the soil in layers of 10-20 and $20-30 \mathrm{~cm}$ from the period of sowing of spring wheat to its harvest.

These data may indicate that in traditional industrial farming, where mineral fertilizers are preferred, to regulate the bulk density of the soil is more appropriate to use plowing. In farming systems where the application of organic fertilizers is preferred, it is permissible to minimize tillage.

\section{References}

[1] Pavlov, O. S. (2012) Change of water-physical indicators of soil in the field of winter wheat depending on the systems of agriculture in the Right-Bank Forest-Steppe of Ukraine. Naukovyi visnyk Natsional noho universytetu bioresursiv i pryrodokorystuvannia Ukrainy, 176, 153-158.

[2] Zhang, Y., Wang, S., Wang, H., Ning, F., Zhang, Y., Dong, Z., . . . Li, J. (2018). The effects of rotating conservation tillage with conventional tillage on soil properties and grain yields in winter wheat-spring maize rotations. Agricultural and Forest Meteorology, 263, 107-117. https://doi.org/10.1016/j.agrformet.2018.08.012

[3] De Notaris, C., Jensen, J. L., Olesen, J. E., Stumpf da Silva, T., Rasmussen, J., Panagea, I., \& Rubæk, G. H. (2021). Long-term soil quality effects of soil and crop management in organic and $\begin{array}{llll}\text { conventional arable } & \text { cropping } & \text { Geoderma, } & \end{array}$ https://doi.org/10.1016/j.geoderma.2021.115383

[4] Fuentes-Llanillo, R., Guimarães, M. F., \& Tavares Filho, J. (2013). Morphology and physical properties of soil according to tillage systems in annual crops. [Morfologia e propriedades físicas de solo segundo sistemas de manejo em culturas anuais] Revista Brasileira De Engenharia Agricola e Ambiental, 17(5), 524-530. https://doi.org/10.1590/S1415-43662013000500009

[5] Kartashov, S. H., Horodetskyi, E. Yu., Dudka, V. S., Moskaliuk, A. A. (2012). Influence of optimal soil bulk density for different crops on yield. Taurian Scientific Bulletin, 78, 21-26.

[6] Elvis López Bravo, Miguel Herrera Suárez, Omar González Cueto, Ciro Iglesias Coronel, Herman Ramon (2016). Effect of Moisture and Soil Compaction on Tillage Operations. Revista Ciencias Técnicas Agropecuarias, 25(1), 32-37.

[7] Blanco-Canqui, H., \& Ruis, S. J. (2020). Cover crop impacts on soil physical properties: A review. Soil Science Society of America Journal, 84(5), 1527-1576 https://doi.org/10.1002/saj2.20129

[8] Khorami, S. S., Kazemeini, S. A., Afzalinia, S., \& Gathala, M. K. (2018). Changes in soil properties and productivity under different tillage practices and wheat genotypes: A short-term study in iran. Sustainability (Switzerland), 10(9) https://doi.org/10.3390/su10093273 
[9] Prymak, P. Panchenko, A. (2015) roductivity change of typical black soils methods of cultivation and fertilizing in the Central Forest-Steppe of Ukraine. Naukovi Dopovidi Nacional'nogo Universitetu Bioresursiv i Prirodokoristuvannâ Ukrainy, 6(55).

[10] Tsyuk, A. A., Tsentilo, L. V., \& Melnik, V. I. (2021). Changes in agrophysical properties of typical type of black type under the influence of fertilizer application and soil treatment. Naukovi Dopovidi Nacional'nogo Universitetu Bioresursiv i Prirodokoristuvannia Ukrainy, 5(93). https://doi.org/10.31548/dopovidi2021.05.007

[11] Chen, Y., Mckyes, E., Tessier, S. (1994). Changes of soil bulk-density during the growing-season under 3 tillage systems. Canadian agricultural engineering, 36(1). 45-49.

[12] Lampurlanés, J., \& Cantero-Martínez, C. (2003). Soil bulk density and penetration resistance under different tillage and crop management systems and their relationship with barley root growth. Agronomy Journal, 95(3), 526-536. https://doi.org/10.2134/agronj2003.5260

[13] Tanchyk, S. P., Manko, Yu. P., Hudz, V. P., Krotinov, O. P., Tsiuk, O. A., Ivaniuk, M. F., Tsentylo, L. V, Kosolap, M. P., Rozhko, V. M., Tarasenko, O. O. «etc.» (2013) Zemlerobstvo. Praktykum [Agriculture. Workbook]. Kyiv, Ukraine: Nilan LTD, 278. 
